\title{
MOGUĆNOSTI PRIMENE BLOCKCHAIN TEHNOLOGIJA NA TRŽIŠTIMA KAPITALA
}

\author{
Miroljub Hadžići \\ Natalija Nedeljković ${ }^{2}$ \\ ${ }^{1}$ Univerzitet Singidunum, \\ Beograd, Srbija \\ ${ }^{2}$ Beogradska berza a.d. \\ Beograd, Srbija
}

Odgovorno lice:

Miroljub Hadžić

e-pošta:

mhadzic@singidunum.ac.rs
Rezime:

Najznačajnije prednosti koje blockchain tehnologije mogu doneti poslovanju, a time i tržištima kapitala, su snižavanje troškova, brzina u saldiranju transakcija, brzina u mogućnosti provere podataka, zaštita podataka, mogućnost provere krajnjeg korisnika i pouzdanost transakcija. Primena blockchain tehnologija na tržištima kapitala još uvek je suočena je sa brojim praktičnim izazovima, koji nisu nepremostivi, zbog čega široku primenu i prihvatanje ovih tehnologija najverovatnije odlažu za najmanje nekoliko godina. Ipak, za manje razvijena tržišta kapitala, koja se tek suočavaju sa izgradnjom infrastrukture kakvu poznaju razvijena tržišta, blockchain tehnologije mogu ponuditi praktična i efikasna rešenja koja mogu biti primenjena u samom kreiranju sistema, što ovim tržištima može doneti i konkurentne prednosti u tehnološkom i operativnom smislu.

Ključne reči:

blockchain tehnologije, berza, tržište kapitala, saldiranje, javnost podataka.

\section{UVOD}

Da bi veliki investicioni fond iz SAD ili Evropske unije kupio akcije na Beogradskoj berzi neophodno je da razmeni podatke sa svojom lokalnom kastodi bankom, koja će, posredstvom drugih, većih kastodi banaka, podatke poslati lokalnoj kastodi banci u Srbiji, lokalnoj banci i brokeru, koji će takođe posredstvom svojih međunarodnih partnera naloge proslediti kolegama u Srbiji, a svi ovi podaci potrebni za obavljanje transakcije na tržištu kapitala moraju stići i do berze na kojoj se transakcija obavlja, lokalnog centralnog registra u kom su evidentirani podaci o vlasništvu nad hartijama od vrednosti, kao i, na kraju procesa, do kompanije čijim se akcijama trguje, kako bi sama kompanija bila obaveštena o promeni vlasništva nad svojim akcijama. Svaki od ovih učesnika na tržištu ima svoje operativne troškove koje naplaćuje od krajnjih kupaca i prodavaca, a dodatno, veliki broj učesnika podrazumeva i veću potrebu za međusobnim usklađivanjem podataka, veću mogućnost greške, ali i nedozvoljenog ponašanja, koje, iako zabranjeno, nikada nije potpuno isključeno na tržištima kapitala.

Inicijalna razmatranja mogućnosti primene blockchain tehnologija na tržištima kapitala ukazala su na mogućnosti da se njihovom primenom može eliminisati potreba za velikim brojem posrednika - brokera, 
centralnih klirinških kuća ili globalnih kastodi banaka. Očekivana unapređenja uključila bi snižavanje troškova održavanja obimnih baza podataka, obrade podataka, kao i sprečavanje manipulacije i zaštite protiv pranja novca na tržištima kapitala. $U$ vreme kada prihodi na tržištima kapitala padaju usled rastućih operativnih troškova, učesnici na tržištima kapitala rado analiziraju mogućnosti koje blockchain tehnologije mogu doneti u unapređenju njihovog poslovanja.

Posebno interesantna činjenica za domaće tržište kapitala, jeste i očekivanje jednog dela autora koji se bave ovim pitanjem da će blockchain tehnologije biti prvo primenjene na manje razvijenim tržištima kapitala, zbog neadekvatnosti procedura evidencije i distribucije podatka na ovim tržištima, kao i nižem stepenu poverenja u regulatore i organizatore trgovanja, kao i na manje likvidnim tržištima, odnosno tržištima sa manjim brojem učesnika.

\section{UVODNA RAZMATRANJA}

\section{Blockchain tehnologije}

Blockchain tehnologiju prvi put je predstavio Satoši Nakamoto, tvorac Bitcoina, 2008. godine, kao lanac na kom se zapisuju sve transakcije ovom valutom, čije je čuvanje i ažuriranje potpuno decentralizovano i u okviru kog su podaci međusobno hronološki povezani kriptografskim šiframa. Iako pojedini autori tvrde da su koncepti na kojima je baziran blockchain već bili korišćeni u oblasti čuvanja podataka i sigurnosti na mrežama, činjenica je da je blockchain doneo određene novine u tehnološkom smislu, koje su rezultovale i u globalnoj pomami za Bitcoin valutom, ali i u detaljnoj analizi mogućnosti primene ove ili sličnih tehnologija u poslovanju, drugim društvenim procesima, kao što su procesi glasanja na izborima, evidencije umetničkih dela, prevoznih sredstava, luksuznog nakita itd. Možda paradoksalno, imajući u vidu da je kreiranje Bitcoina Nakamoto obrazložio upravo željom da ljudima omogući da izbegnu i na neki način se oslobode od banaka i finansijskih posrednika, bankarska zajednica i finansijske institucije danas su među liderima pokušaja primene tehnologija sličnih blockchainu u rešavanju sopstvenih problema i unapređenju poslovanja.

Strogo terminološki posmatrano blockchain tehnologija je specifična tehnologija koja se koristi za evidentiranje transakcija Bitcoin valutom, dok se druge slične tehnologije najčešće nazivaju „distributed ledger“ tehnologijama, odnosno tehnologijama „distribuiranih registara". Kako je blockchain već uglavnom prihvaćen u domaćoj terminologiji za potrebe ovog rada biće korišćen upravo ovaj izraz, uz eventualna dodatna objašnjenja u slučajevima kada se analizirane tehnologije značajnije razlikuju od specifičnosti blockchain-a.

Osnovne karakteristike blockchain tehnologije bitne za poslovnu implementaciju mogu se sumirati na sledeći način:

- Distribuirani podaci, tako da svaki učesnik u procesu ima pristup celoj bazi podataka, bez postojanja centralnog mesta skladištenja podataka, čime se istovremeno izbegava jedna tačka u sistemu koju je moguće napasti da bi se ugrozio ceo sistem;

- Mogućnost da svi učesnici u direktnoj komunikaciji obavljaju transakcije koje međusobno validiraju na samom lancu, tako da ne postoji potreba da bilo kakva institucija posreduje ili validira obavljene transakcije;

- Anonimnost - vidljiva je samo blockchain adresa učesnika;

- Nepromenljivost zapisa - nakon validacije transakcije u blockchainu nju više nije moguće izmeniti bez izmene svih naknadnih zapisa, što je sprečeno odgovarajućom kriptografskom zaštitom;

- Mogućnost ugrađivanja računske logike i programiranja realizacije događaja ili transakcija u samoj strukturi lanca, koji se realizuju po ispunjavanju zadatih preduslova i postaju momentalno verifikovani - „pametni ugovori” (smart contracts).

\section{Izazovi na savremenim tržištima kapitala}

Trgovanje na berzama, odnosno organizovanim tržištima, svugde u svetu, u manjoj ili većoj meri, u zavisnosti od razvijenosti same privrede i stepena tržišnosti ekonomije, danas je suočeno sa sličnim izazovima. Ti problemi se ukratko mogu sumirati na sledeći način:

- Troškovi posrednika i institucija tržišta - bilo da individualni investitor ili veliki fond žele da trguju na nekoj od svetskih berzi oni će u tom procesu nužno morati da angažuju ili koriste usluge posrednika, banaka, kastodi banaka, registara hartija od vrednosti i privrednih društava, berzi, analitičara, konsultanata itd. Svaki od ovih učesnika za svoje usluge naplaćuje određenu proviziju, što na globalnom nivou dovodi do značajnog učešća posrednih troškova u ukupnoj vrednosti 
trgovanja na berzama. Svako od učesnika na tržištu ima i svoje sopstvene baze podataka i softvere koji se koriste za obradu i distribuciju podataka, a skladištenje, preuzimanje i prevođenje podataka iz ovih baza stvara dodatne troškove učesnicima. Dodatni troškovi na tržištima kapitala uključuju i troškove povezane sa rizicima likvidnosti i pouzdanosti druge strane u transakciji.

- Poverenje - čak ni vodeća tržišta finansijskih instrumenata nisu otporna na probleme kao što su nekorektni ili nepotpuni finansijski izveštaji, manipulacije na tržištu, insajdersko trgovanje itd. Procenjuje se da $45 \%$ tržišnih učesnika bude žrtva poslovnog kriminala svake godine [4]. Imajući u vidu da se na berzama trguje očekivanjima i da svako urušavanje poverenja dovodi do obaranja vrednosti što pojedinačnih kompanija, što tržišta uopšte, izuzetno je bitno pronaći načine da se svi oblici nedozvoljenih ponašanja minimiziraju. Kada bi poverenje na tržištima kapitala bilo besprekorono brojni poslovi i usluge koje pružaju različiti subjekti na tržištu bi postali suvišni, a time i troškovi koje oni donose u procesu trgovanja.

- Brzina poslovanja - iako samo obavljanje transakcija na berzama važi za brz i dinamičan proces, ono što mu prethodni ili dolazi posle njega (prikupljanje i obrada podataka, saldiranje, izveštavanje, distribucija podataka o obavljenim transakcijama između različitih učesnika), često su vremenski zahtevni procesi koji uključuju i različite forme u kojima se podaci čuvaju i obrađuju, potrebu da se podaci preuzimaju i prevode iz jednog oblika izveštaja u druge itd. Sve ovo, osim što povećava troškove, istovremeno i usporava procese izveštavanja, analize podataka i, $u$ krajnjoj liniji, samu realokaciju kapitala ka onima koji imaju najveći potencijal za njegovo uvećanje.

Kombinacija pojedinih ili svih aspekata blockchain tehnologije može savremenim tržištima kapitala ponuditi prevazilaženje nekih od pobrojanih problema, a, što je možda još značajnije, i inovativna rešenja za kojima potreba ranije nije direktno uočena, a čija bi primena donela značajna unapređenja u ovoj oblasti.

\section{MOGUĆNOSTI PRIMENE BLOCKCHAIN TEHNOLOGIJA NA TRŽIŠTIMA KAPITALA}

Kombinacija pojedinih ili svih aspekata blockchain tehnologije može savremenim tržištima kapitala ponuditi prevazilaženje nekih od prethodno pobrojanih problema, a, što je možda još značajnije, i inovativna rešenja za kojima potreba ranije nije direktno uočena, a čija bi primena donela značajna unapređenja u ovoj oblasti.

Jedna od prvih mogućih primena blockchain tehnologija u poslovanju na tržištima kapitala uočena je u oblasti saldiranja transakcija. Saldiranje transakcija predstavlja proces u kom kupci akcija postaju njihovi vlasnici, a prodavci dolaze u posed novca. Na tržištima kapitala, od momenta prodaje do momenta saldiranja najčešće prođu dva radna dana $(\mathrm{T}+2)$, što je posledica činjenice da se u tom periodu kupcima i prodavcima ostavlja vreme da na računima obezbede sredstva koja su im potrebna za realizaciju transakcije. Unapređenje i ubrzavanje procesa saldiranja, uz istovremenu sigurnost koju blockchain tehnologija nudi putem onemogućavanja tzv. dvostruke prodaje, odnosno istovremene prodaje jedne aktive dvojici kupaca ili korišćenju istih novčanih sredstava za dve kupovine, značajno bi doprinelo snižavanju troškova i povećavanju poverenja na tržištima.

I sam proces trgovanja na berzama mogao bi biti unapređen upotrebom blockchain tehnologije, imajući u vidu da ona pretpostavlja međusobne transakcije između zainteresovanih učesnika bez postojanja posrednika (P2P transakcije). Trgovanje na berzi nezamislivo je bez brokera, što rezultuje u povećavanju troškova transakcije, ali čak ostavlja i mogućnosti dodatnih manipulacija na tržištu, od strane posrednika na račun sopstvenih klijenata. Za razliku od transakcija na tržištima kapitala, koje se neminovno baziraju na poverenju između učesnika, blockchain transakcije ne pretpostavljaju nikakvo poverenje između strana u transakciji, pa čak ni otkrivanje njihovih identiteta.

Indirektno snižavanje troškova na tržištima moglo bi biti ostvareno i snižavanjem obaveznog kolaterala koji investitori moraju da deponuju u institucijama koje služe za obezbeđivanje tržišta (najčešće tzv. CCP - Central Clearing CounterParties), čime bi veća sredstva bila raspoloživa za trgovanje.

Sledeća mogućnost primene blockchain tehnologija na tržištima kapitala uočena je u oblasti izveštavanja javnih akcionarskih društava. Periodični izveštaji koje kompanije objavljuju govore o prošlosti, o onome što se u poslovanju kompanije dogodilo pre tri, šest ili 12 meseci, dok investitore interesuje ono što se u kompaniji dešava danas, ukoliko već nisu u mogućnosti da predvide budućnosti i ono što će se sutra dešavati u kompaniji. Takođe, periodični izveštaji listiranih kompanija moraju biti revidirani od strane revizorskih kuća, što dodatno 
povećava troškove poslovanja. Blockchain tehnologija omogućila bi računovodstveno izveštavanje u gotovo realnom vremenu, evidentiranjem i javnim publikovanjem svih promena koje se dešavaju u novčanim i bilansnim tokovima kompanije, čime bi praktično svi podaci o onome što se danas dešava u kompaniji mogli biti dostupni investicionoj javnosti, bez mogućnosti naknadne izmene podataka ili njihove manipulacije, što je, ponovo, posebno važno u kontekstu poverenja na tržištu.

Još jedan od problema za koji je uočeno da bi blockchain tehnologija mogla da doprinese njegovom rešavanju, a često predstavlja izvor neefikasnosti u savremenim tržišnim ekonomijama, jeste i proces glasanja na akcionarskim skupštinama. Posebno u slučaju velikih akcionarskih društava, koja imaju i po nekoliko hiljada akcionara, sprovođenje prava glasanja na skupštini akcionara je problematično za manje akcionare, a liste akcionara u samim kompanijama su često neažurne i sadrže pogrešne ili zastarele podatke. Pored izostanka direktne motivacije da se učestvuje na skupštinama akcionara, zbog malog učešća u vlasništvu, sam proces glasanja podrazumeva ili fizičko prisustvo na skupštini akcionara, ili davanje posebnih ovlašćenja advokatima ili drugim posrednicima, što je često vremenski zahtevan proces koji uključuje i brojne birokratske procedure - overu punomoćja, prevode itd. Glasanje putem blockchain tehnologije omogućilo bi, ne samo brže i efikasnije izražavanje sopstvenog stava za vlasnike akcija, već bi i samoj kompaniji pružilo mogućnost da analizira rezultate i stavove akcionara prema njihovom vlasništvu, karakteristikama (pol, uzrast, obrazovanje, država iz koje dolaze itd).

Ono što posebno otvara nove mogućnosti u oblasti primene blockchain tehnologije na tržištima kapitala jesu tzv. "pametni ugovori", koji se mogu automatski realizovati po ispunjavanju određenih uslova. Distribucija novih akcija iz dobiti postojećim akcionarima putem pametnih ugovora bi postala automatska, uz snižavanje troškova i angažovanih resursa, a slično bi važilo i za isplate kupona u trgovanju obveznicama, ispunjavanje uslova iz derivativnih materijala ili korporativne poslove koje kastodi banke obavljaju za svoje klijente uz angažovanje značajnih ljudskih resursa.

\section{PRAKTIČNE IMPLIKACIJE UPOTREBE BLOCKCHAIN TEHNOLOGIJANA TRŽIŠTIMA KAPITALA}

Tehničke mogućnosti koje blockchain tehnologija može ponuditi učesnicima tržišta kapitala, same po sebi ne donose posebnu korist ukoliko istovremeno ne utiču i na rešavanje nekih od problema sa kojima se tržišta u praksi susreću. U tom smislu bitno je sagledati koristi od primene blockchain tehnologija u ovoj oblasti i ukazati na potencijalne probleme koji se u praksi mogu pojaviti i oceniti njihov uzajamni odnos.

\section{Mogućnosti primene blockchain tehnologija u praksi tržišta kapitala}

Ostvarivanje koristi od primene blockchain tehnologija na tržištima kapitala u praksi je uslovljeno različitim oblicima modela ovih tehnologija koji bi bili primenjeni - da li bi u pitanju bile mreže koje omogućavaju potpunu transparentnost učesnika ili bi bila omogućena anonimnost, da li bi postojali neki centralni čvorovi i institucije koje bi ipak zadržale deo nadležnosti u vezi sa davanjem dozvole za pristupanje drugim korisnicima ili bi distribucija podataka i „demokratičnost mreže“ bila potpuna, kao što je slučaj sa Bitcoin blockchainom itd. U nastavku rada prikazane su moguće opcije praktične upotrebe i modifikacija tehnologija sličnih blockchain-u, u zavisnosti od polaznih pretpostavki same arhitekture postavljenog sistema.

Većina autora koja analizira mogućnosti primene rešenja baziranih na blockchain tehnologijama na tržištima kapitala saglasna je da bi ove tehnologije nesporno doprinele unapređenju kvaliteta korporativnog upravljanja u savremenim akcionarskim društvima. Ovaj efekat bi pre svega bi postignut olakšavanjem i unapređivanjem procesa glasanja na akcionarskim skupštinama, javnošću podataka iz knjiga akcionara, kao i njihovim bržim ažuriranjem. Ukoliko bi svi podaci o akcionarima kompanije bili poznati neposredno nakon nastanka kupoprodajne transakcije, a ne nakon uobičajenog perioda od dva dana, koliko je potrebno za saldiranje, svi učesnici u trgovanju odmah bi znali o prodaji akcija od strane velikih fondova, potezima menadžera i tzv. „akcionara aktivista" u trgovanju. Na taj način, menadžerima bi bila smanjena mogućnost neopaženog insajderskog trgovanja, dok bi akcionari aktivisti putem prodaje ili kupovine akcija efikasnije slali poruke javnosti o tome šta misle o poslovanju društva ili donetim poslovnim odlukama [6]. Takođe, javnost podataka objavljenih na blockchain lancu sprečila bi menadžere da retroaktivno upisuju vlasništvo nad akcijama ili obavljaju druge korporativne radnje koje im obezbeđuju povlašćenu poziciju u odnosu na spoljne akcionare [6]. Prelaženje određenog praga vlasništva nad hartijama od vrednosti pojedinačne kompanije bilo bi automatski vidljivo, tako da vlasnici ne bi imali dodatnu birokratsku obavezu da o tome 
obaveštavaju tržište. Iako je korist upotrebe blockchain tehnologija u kontekstu korporativnog upravljanja u akcionarskim društvima uglavnom nesporna, sa druge strane, pojedini autori ističu nedoumicu da li bi ovakvi rezultati imali loše ekonomske posledice po pojedinačna preduzeća, jer bi, kompenzacije koje menadžeri ostvaruju putem, iako zabranjenog, ali ipak prisutnog trgovanja na bazi insajderskih informacija, kompanije morale da plaćaju menadžerima kroz platu ili druge nadoknade, kako bi nivo njihovog zadovoljstva ostao nepromenjen u odnosu na trenutno stanje [6].

Takođe, blockchain tehnologije bi u značajnoj meri u praksi mogle doprineti usklađivanju i poštovanju zahteva „poznavanja druge strane u transakciji“ (Know Your Customer) i borbi protiv pranja novca, kao i značajnom snižavanju troškova ovih aktivnosti. Nakon skandala koji su pogodili finansijsku industriju početkom XXI veka zahtevi za poznavanjem druge strane u transakciji su, usled pooštravanja regulacije ove oblasti, postali značajna stavka u troškovima poslovanja za finansijske institucije [2]. Javnost podataka o svim vlasnicima akcija pojedinog društva, kao i mogućnost hronološkog praćenja svih transakcija značajno bi umanjila mogućnost koja sada, i pored značajnih mera predostrožnosti, postoji, da se iza određenih klijenata u trgovanju akcijama kriju oni koji su novac stekli na ilegalan način ili su na drugi način kompromitovani. Takođe, procesi usklađivanja sa ovim regulatornim zahtevima mogli bi biti znantno jeftiniji i podrazumevali bi manje administriranja, vremena i obrade podataka. Blockchain tehnologija omogućila bi javno publikovanje „bogatijih“ baza podataka, u kojima bi, pored direktnih vlasnika, bile vidljive i znatno dublje strukture vlasništva i odnosa između povezanih lica. Dodatna potencijalna korist ovakvog načina objavljivanja podataka manifestovala bi se i kroz mogućnost da akcionarska društva jednostavnije spreče i reaguju na pokušaj neželjenog preuzimanja, ukoliko bi imala kompletniji uvid u celokupnu vlasničku strukturu kupaca njihovih akcija [6]. Poznavanje druge strane u transakciji posebno bi doprinelo snižavanju rizika i troškova regulatornih usklađivanja u trgovanju derivatima [2].

Uvećavanje likvidnosti na tržištima, kao rezultat upotrebe blockchain tehnologija, prvenstveno bi mogla biti ostvarena na bazi snižavanja troškova provizija posrednika i snižavanja bid-ask spredova (razlike između ponuđene kupovne i prodajne cene na tržištu) i pojednostavljivanja procedura trgovanja, dok bi rast efikasnosti tržišta bio rezultat transparentnog trgovanja i bržeg snižavanja informacione asimetrije između informisanih i manje informisanih investitora, usled javnog objavljivanja transakcija. Takođe, kao i ostale inovativne tehnologije koje snižavaju procenat greške, i blockchain tehnologije bi minimiziranjem grešaka dodatno doprinela uštedama.

Jedna od najvećih kontroverzi u primeni blockchain tehnologija u praksi odnosi se na analizu njihove primene u procesu saldiranja. Iako je nesporno da bi sam proces saldiranja mogao biti ubrzan primenom ovih tehnologija, a centralni kliring transakcija potpuno suvišan, pitanje je da li bi to doprinelo unapređenju tržišta kapitala u smislu efikasnosti i snižavanja troškova. Pod pretpostavkom da je za omogućavanje trgovanja finansijskim instrumentima neophodno postojanje lanca novca i lanca hartija od vrednosti, klijenti bi, ukoliko raspolažu novcem, odnosno akcijama na navedenim lancima mogli da međusobno zaključe transakciju momentalno, bez uključivanja posrednika i centralnog registra. Međutim, trajanje saldiranja od dva dana danas nije uzrokovano nemogućnošću registara da proces završe u kraćem vremenskom roku, već pre svega pružanjem mogućnosti klijentima da realizuju transakciju, tj. obezbede novac na računu neophodan za kupovinu trgovanih hartija od vrednosti, ili da pozajme hartije od vrednosti za koje su doneli odluku da ih prodaju na kratko (ova praksa nije zastupljena na srpskom tržištu kapitala, ali jeste na većini drugih). U tom smislu, skraćivanje procesa saldiranja oslobodilo bi više kapitala za trgovanje, ali bi prihodi onih koji se bave pozajmljivanjem hartija od vrednosti bili smanjeni [2], što ovo pitanje čini još jednim od onih na koje je tek neopdhodno dati odgovor da li bi koristi od primene blockchain tehnologija na tržištima kapitala bile veće od eventualnih troškova i gubitaka.

\section{Izazovi u mogućnostima upotrebe blockchain tehnologija na tržištima kapitala}

Da bi primena blockchain tehnologija na tržištu kapitala bila sagledana kompletno neophodno je razmotriti i očekivane načine na koji bi ova tehnologija mogla da praktično postane deo ovih velikih sistema. U tom smislu, treba imati u vidu da su institucije tržišta kapitala glomazni sistemi, često sa gradualno nadograđivanim IT rešenjima, inertni, ne samo zbog svoje arhitekture, već, u velikoj meri, i zbog prateće regulative kojom se praktično štiti poverenje u tržište i svi učesnici. Skoro je nesporno da bi, da se tržišta kapitala danas po prvi put formiraju, njihova informaciona tehnologija bila bazirana upravo na tehnologijama manje ili više sličnim blockchain, ali pitanje je koliko brzo i na koji način 
ova rešenja mogu da se primene u postojećim okvirima. Pre svega, tu je pitanje troškova. U registrima hartija od vrednosti, učesnika na tržištu, privrednih društava i računovodstvenih izveštaja postoje velike količine podataka koji nisu uvek međusobno kompatibilni. Uvođenje blockchain tehnologije koja bi omogućila jedinstvenu i efikasnu obradu i razmenu kompatibilnih podataka podrazumevala bi izmenu arhitekture ovih velikih sistema, što je izuzetno troškovno i vremenski zahtevno. Dodatno, ovakav poduhvat verovatno bi trebalo da bude izveden kroz sinhronizovanu, radikalnu akciju svih učesnika na lokalnom tržištu ili, čak, na internacionalnom nivou, što otvara dodatna pitanja međusobne usklađenosti, zajedničke motivacije i interesa, usklađenosti regulative itd. Druga moguća opcija prihvatanja blockchain tehnologija od strane učesnika na tržištu kapitala, koja nije inicirana "odozgo", podrazumevala bi pionirske poduhvate manjih učesnika na tržištu, ali ovu opciju većina autora odbacuje, imajući u vidu upravo veličinu ključnih subjekata na tržištima danas. Stručna zajednica očekuje da će blockchain tehnologije u preovlađujućoj meri moći da budu primenjene na tržištu kapitala tek kada prednosti ekonomije obima budu mogle biti iskorišćene i kada bude bilo moguće jasno kvantifikovati koristi u odnosu na troškove [2], [3], [5], kao i da će masovna praktična primena ovih tehnologija najverovatnije biti inicirana od strane regulatora ili centralnih institucija tržišta [1], [3].

Takođe, u razmatranju praktične primene blockchain tehnologija na tržištima kapitala potrebno je uzeti u obzir i činjenicu da je malo verovatno da bi regulatori i druge centralne institucije lako pristali na otvorene sisteme koje bi, sa jedne strane, svako na svetu mogao da menja, ali i u kojima bi im, sa druge strane, potpuno bila uskraćena mogućnost da naknadno menjaju prethodno registrovane promene (npr. poništavanje transakcija kada se za tim ukaže potreba), kao što je slučaj sa trgovanjem Bitcoinom. U tom smislu većina autora se slaže da bi se tehnologije koje bi bile primenjene na tržištu kapitala razlikovale od blockchain tehnologije u tom smislu što to ne bi mogli da budu potpuno distribuirani registri, već bi jedan ili nekoliko ovlašćenih učesnika ipak moralo da ima neki vid centralizovane pozicije [3]. To ponovo otvara pitanja monopola nad podacima, jedinstvene tačke u kojoj bi moglo da dođe do problema ili greške i same efikasnosti centralizovanih sistema. Takođe, primenom blockchain tehnologija, u obliku u kom su one danas prihvaćene, u poslovima kliringa i saldiranja transakcija ogromne količine novca i vlasništva nad hartijama od vrednosti bile bi transferovane u toku jednog trgovanja, bez mogućnosti primene algoritama koje registri danas primenjuju za krajnji kliring hartija od vrednosti na kraju trgovanja.

Dodatno pitanje koje bi bilo neophodno rešiti u praktičnoj primeni blockchain tehnologija na tržištima kapitala jeste i postojanje različitih „lanaca“, odnosno registara, i njihove usklađenosti. Polazna pretpostavka u većini razmatranja jeste da postoji lanac novca i lanac akcija za pojedinačno preduzeće, ali praksa bi neminovno postavila i pitanje međusobnog povezivanja lanaca akcija različitih preduzeća, kao i povezivanja lanaca sa već postojećim bazama podataka, formiranje lanaca finansijskih izveštaja, identiteta pojedinačnih klijenata i strukture vlasništva, pitanje da li bi sve akcije na jednom tržištu bile evidentirane na jednom lancu ili bi za svako pojedinačno preduzeće postojali odvojeni lanci, da li bi bilo moguće evidentirati sve hartije na svetu na jednom lancu, i na taj način ostvariti jedinstveno globalno tržište itd.

Blockchain tehnologije, iako nude bezbednost i javnost podataka, u ovom trenutku još uvek ne rešavaju pitanje momentalne verifikacije zabeleženih podataka, što može predstavljati problem u slučajevima kada je to neophodno, npr. na tzv. order-driven tržištima, kao što je i srpsko tržište kapitala. Takođe, postavlja se pitanje koji bi se trenutak u praksi vodio kao trenutak konačne verifikacije obavljene transakcije, u smislu „finalnog setlmenta" na način na koji je to regulisano u regulativi svetskih tržišta kapitala danas [5].

$\mathrm{Na}$ finansijskim tržištima neophodno je procesuirati desetine hiljada transakcija u sekundi, dok npr. Bitcoin blockchain u ovom trenutku može da procesuira manje od 10 transakcija $\mathrm{u}$ istom vremenskom periodu. $\mathrm{U}$ tom smislu, ni high-frequency trgovanje, na način na koji danas funcioniše, u ovom trenutku ne bi moglo biti podržano putem blockchain tehnologija, već se primena ovih tehnologija, posebno u prvoj fazi, očekuje na manje likvidnim tržištima, sa manjim brojem učesnika u trgovanju [2].

\section{ZAKLJUČAK}

Iako su rešenja koja blockchain tehnologije nude savremenim tržištima kapitala izazovna i obećavajuća, široka primena u praksi će biti moguća tek nakon prevazilaženja brojnih identifikovanih, ali i još neuočenih prepreka koje će biti otkrivene tek sa širom praktičnom primenom ovih tehnologija. Idealno zamišljeno tržište kapitala bazirano na tehnologijama distribuiranih registara rezultovalo bi u prevazilaženju brojnih neefikasnosti 
koje danas karakterišu tržišta kapitala, u kom bi svi tržišni učesnici radili sa jedinstvenim podacima iz zajedničkih baza podataka, skoro u realnom vremenu i gde bi pomoćne operacije bile ili maksimalno pojednostavljene ili sasvim bespotrebne.

Činjenica je da se ni stručna javnost u ovom trenutku ne slaže u potpunosti u vezi sa mogućim praktičnim primenama i arhitekturom tehnologija sličnih blockchain-u koje bi donele najveće koristi tržištima kapitala. Nisu u pitanju samo tehnološki izazovi, već i neophodne pretpostavljene izmene regulative, kao i obimne izmene ustaljene operativne prakse, što bi moglo da doprinese dodatnim troškovima i opiranju ovim promenama, kao i značajnom usporavanju celokupnog procesa. Primena blockchain tehnologija verovatno bi na duži rok donela i potpunu promenu uloga pojedinih učesnika na tržištu, u smislu da bi posrednici više mogli da se koncentrišu na savetodavne usluge, a centralni registri i kastodi banke bi verovatno klijentima pružali dodatne usluge koje danas ne postoje.

Sve u svemu, malo je verovatno da će blockchain tehnologije na tržištima kapitala biti primenjene u kratkom roku, a vrlo je verovatno da će sa nastankom novih proizvoda i rešenja, koje će sami učesnici inicirati kako bi povećali svoju konkurentnost, u narednih nekoliko godina na tržištima biti primenjena mnoga rešenja bazirana upravo blockchain tehnologijama.

\section{LITERATURA}

[1] Buitenhek, M., 2016. Understanding and applying Blockchain technology in banking: Evolution or revolution?. Journal of Digital Banking, 1(2), pp.111-119.

[2] Kurki, J.P.J., 2016. Blockchains and distributed ledgers in financial world-Opportunity or threat to banks? Tampere University of Technology

[3] Mainelli, M. and Milne, A., 2016. The impact and potential of blockchain on securities transaction lifecycle, SWIFT Institute, Working Paper No 2015007

[4] Tapscott, A. and Tapscott, D., 2017. How blockchain is changing finance. Harvard Business Review, 1 .

[5] Wyman, O., 2016. Blockchain in capital markets: the prize and the journey, Euro Clear.

[6] Yermack, D., 2017. Corporate governance and blockchains. Review of Finance, 21(1), pp.7-31. 